Review

\title{
Beneficial Effects of Monascus sp. KCCM 10093 Pigments and Derivatives: A Mini Review
}

\author{
Daehwan Kim ${ }^{1,2}$ and Seockmo $\mathrm{Ku}^{3, * \text { iD }}$ \\ 1 Laboratory of Renewable Resources Engineering, Purdue University, West Lafayette, IN 47907-2022, USA; \\ kim1535@purdue.edu \\ 2 Department of Agricultural and Biological Engineering, Purdue University, West Lafayette, \\ IN 47907-2093, USA \\ 3 Fermentation Science Program, School of Agribusiness and Agriscience, College of Basic and Applied \\ Sciences, Middle Tennessee State University, Murfreesboro, TN 37132, USA \\ * Correspondence: Seockmo.Ku@mtsu.edu; Tel.: +1-765-637-1975
}

Received: 1 November 2017; Accepted: 18 December 2017; Published: 3 January 2018

\begin{abstract}
The production of Monascus pigments and related byproducts, via microbial fermentation, has been broadly utilized as coloring by traditional food industries and as a natural textile dye. In addition to these traditional purposes, Monascus pigments have been recently favored for a variety of commercial and academic purposes. Pigments and derivatives formed during Monascus fermentation have pharmaceutical and clinical properties that can counteract common diseases, including obesity, type- 2 diabetes, and cancer. Various research attempts have investigated the optimum conditions for this derived compound synthesis, as well as the still-unknown bio-functional effects. Recently, several studies were conducted using Monascus sp. KCCM 10093 and its derivatives. These experimental outcomes potentially reflect the bio-functional features of Monascus sp. KCCM 10093. However, no publication to date provides an overview of Monascus sp. KCCM 10093's unique metabolite products, functionalities, or biological pathways. In order to develop profitable commercial applications of Monascus sp. KCCM 10093, it is necessary not only to conduct continuous research, but also to systematically organize previous Monascus studies. The goals of this review are to investigate the current derivatives of Monascus sp. KCCM 10093 pigments-some of which have demonstrated newly-identified functionality-and the relevant uses of these molecules for pharmaceutical or nutraceutical purposes.
\end{abstract}

Keywords: bioconversion; derivatives; Monascus fermentation; microbial pigments; secondary metabolites

\section{Introduction}

In the past, food was used to eliminate hunger and meet nutritional requirements. In contemporary society, food is being used as a means to eliminate disease and improve our quality of life. Food consumers' concerns regarding how foods and food supplements influence health have increased in recent years [1]. Functional food (also known as superfood, nutraceutical, and dietary supplements) comprises an actively growing business sector [2]. Therefore, the food markets of major developed countries are being driven by the concept of food functionality [3,4]. Food supplements are being used to provide additional essential nutrients, bio-functionality, and counteract health issues. The health-benefit characteristics of food supplements are expected to have a positive impact on worldwide industrial demand. The world functional food market was valued at $\$ 129.39$ billion USD in 2015 [5]. Grand View Research estimates that the functional food market will steadily increase over the next eight years, due to growing consumer interest in healthy eating [6]. 
Among the various microbial-derived food subsidiaries, many East Asian providers have lately become interested in the application of edible fungi. In fact, this research trend is unsurprising [7]. Although the Monascus genus (filamentous fungus) was named in 1884 by van Tieghem, its various fermented foods and commodities have been used for thousands of years in East Asian countries and regions, including China, Korea, Indonesia, Okinawa, the Philippines, and Taiwan [8,9]. Traditionally, the people of East Asia have used a variety of fungi (e.g., Actinomucor spp., Amylomyces spp., Rhizopus spp., Monascus spp., Neurospora spp., Aspergillus spp., Penicillium spp., Torulopsis spp., Trichosporon spp., and Zygosaccharomyces spp.) [10] to produce various fermented food products. Food consumers have traditionally used fungi for food processing, which has led to the welcome addition of fungi into food. The Monascus fungus has been widely utilized for nearly two thousand years, as a natural food coloring agent, food antiseptic, and alternative medicine that eases digestion and soothes pain. Monascus-fermented red mold rice first appeared in a 1590 Chinese medicine book that detailed its use as a valuable coloring, flavoring, preservative, and therapeutic agent [11,12]. Red mold rice is synonymous with Hongqu, Honchi, Angkhak, and Red Chinese rice in China, Koji and Red Koji in Japan, Red mold in the U.S., and Rotschimmelreis in Europe [13,14].

It is reported that Monascus pigments can exist and be produced in a cell-bound form [15-17]. These products contain beneficial secondary metabolites, also called azaphilones [18]. Monascus can generate more than 90 distinct molecules [19]. There are six known Monascus pigments in three colors: orange (monascorubrin and rubropunctatin), yellow (ankaflavin and monascin), and red (monascorubramine and rubropunctamine) (Figure 1) [20].
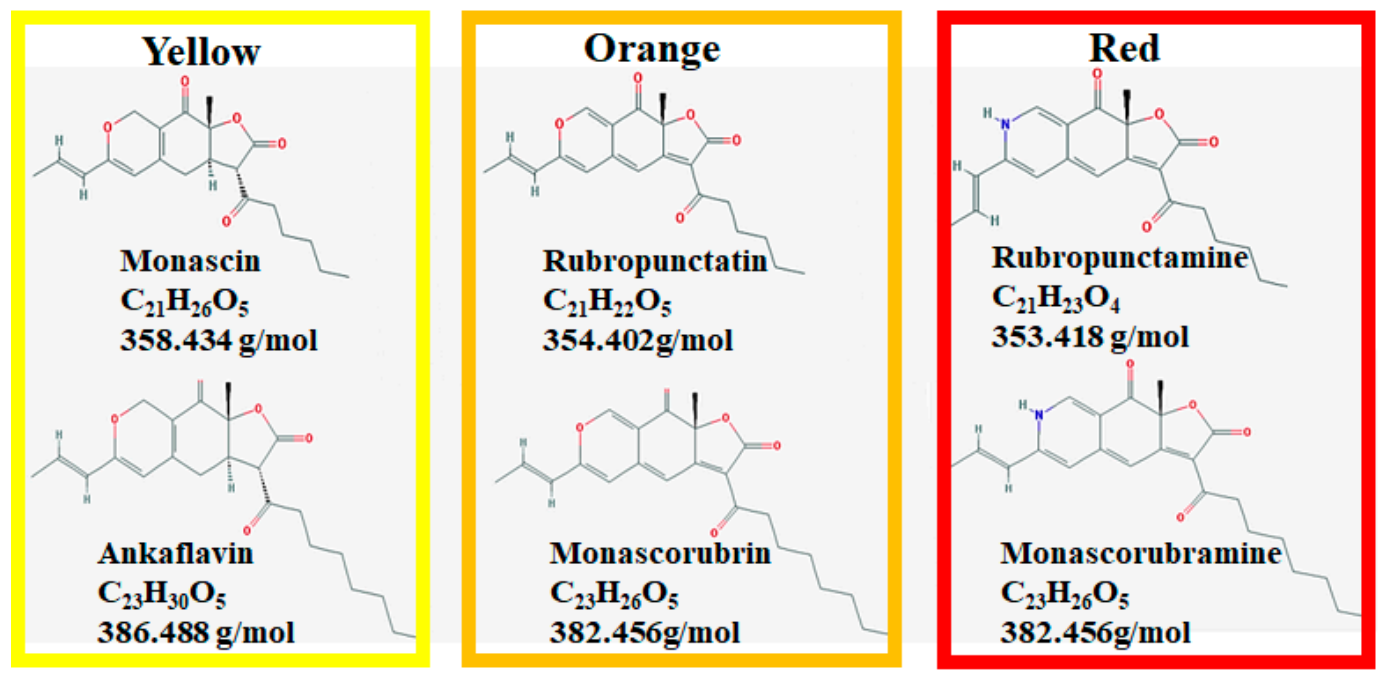

Figure 1. Six major Monascus pigments' chemical structures.

Monascus growth and the production of its derived byproducts are easily subject to change based on culture conditions. For instance, octanoic acid, a medium-chain fatty acid, is essential to Monascus pigment color changes, via its chromophore site binding [21]. Previous works found that the trans-etherification of octanoic acid causes the formation of orange pigments; a decrease in orange pigments (mainly monascorubrin) generates yellow pigments, and the proliferation of orange pigments increases the production of red pigments [18,21-23]. Other studies reported that morphological change is a major contributor to cell growth and pigment production. Shin et al. [24] found that co-cultivations of Saccharomyces cerevisiae or Aspergillus oryzae in Monascus cultures increased cell growth and pigment yield, likely due to the hydrolytic enzymes produced from $S$. cerevisiae or Asp. oryzae. Hydrolytic enzymes, such as amylase and chitinase, caused cell wall degradation and morphological change in Monascus, which may have induced the cells to produce protective molecules (e.g., hydrophobic pigments) to defend against cellulolytic enzyme attacks. Further work 
done by Ju et al. [25] optimized red pigment production, by controlling chitinase activity during Monascus fermentation. The addition of an S. cerevisiae culture-filtered solution (containing chitinase) and maintained chitinase activity improved cell mass and pigment concentration. Kim et al. [26] also demonstrated that morphological control of Monascus in seed cultures augmented the pigment production in scale-up performances, from a $5 \mathrm{~L}$ to $300 \mathrm{~L}$ reactor, by controlling impeller tip speed and oxygen transfer rate $\left(\mathrm{K}_{\mathrm{L}} \mathrm{a}\right)$. Moreover, Monascus pigment concentrations, color profiles, and chemical properties are highly related to the particular strain [27], medium substrate [28-30], nitrogen and oxygen concentrations [29,31,32], pH [33,34], temperature [35], and mixing conditions [35,36]. Over 30 Monascus strains have been documented. Three strains (M. Pilosus, M. purpureus, and M. ruber) have been studied extensively and applied in industry [15]. The conventional Monascus species used as food coloring agents in Asian countries as well as universally-perceived genera are summarized in Table 1.

Table 1. Summary of Monascus species utilized to produce fermented pigments.

\begin{tabular}{|c|c|c|c|c|}
\hline Species & Strain & Medium & Color & Reference \\
\hline Monascus sp. & KCСM 10093 & Chemically defined medium & Red, orange & {$[22,23,37]$} \\
\hline Monascus sp. & KB20M10.2 & GPMY (chemically defined medium) & Yellow & {$[17,38]$} \\
\hline Monascus sp. & ATCC 16436 & MP I, II and III (chemically defined medium) & Orange, yellow & {$[8,39]$} \\
\hline Monascus sp. & J101 & Chemically defined medium & Red, yellow & {$[24,25,40]$} \\
\hline Monascus sp. & B683 & Chemically defined medium & Red, yellow & [41] \\
\hline Monascus sp. & TTWMB 6093 & Chemically defined medium & Red & [42] \\
\hline Monascus kaoliang & ATCC 26264 & Solid culture medium & Orange, yellow & [9] \\
\hline Monascus bisporus & ATCC 36964 & $319^{1}$ & Yellow & [43] \\
\hline Monascus eremophilus & ATCC 62925 & $319^{1}$ & Orange & {$[44]$} \\
\hline Monascus floridanus & ATCC 64205 & $336^{1}$ & Orange & {$[44]$} \\
\hline Monascus lunisporas & ATCC 204397 & $319^{1}$ & Orange & {$[45]$} \\
\hline Monascus sanguineus & ATCC 200613 & $325^{1}$ & Red & [46] \\
\hline Monascus pilosus & ATCC 16363 & $325^{1}$ & Orange & {$[44]$} \\
\hline Monascus ruber & ATCC 15670 & $336^{1}$ & Orange & [31] \\
\hline Monascus ruber & ATCC 96218 & Chemically-defined medium & Red & [21] \\
\hline Monascus ruber & ССТ 3802 & Chemically-defined medium & Red, orange, yellow & {$[28,32,36]$} \\
\hline Monascus ruber & $102 w$ & Chemically-defined medium & Red & [47] \\
\hline Monascus ruber & LEB A 1-3 & $\mathrm{PDA}^{2}$ & Red & [48] \\
\hline Monascus purpureus & ATCC 16365 & $325^{1}$ & Orange & {$[44]$} \\
\hline Monascus purpureus & IMI 210765 & $\mathrm{PDA}^{2}$ & Red, yellow & [49] \\
\hline Monascus purpureus & NRRL 1992 & $\mathrm{PDA}^{2}$ & Yellow & {$[50]$} \\
\hline Monascus purpureus & CCM8152 & Chemically-defined medium & Red & {$[51,52]$} \\
\hline
\end{tabular}

${ }^{1}$ ATCC designed medium [53]; ${ }^{2}$ Potato dextrose agar.

Over the past few decades, considerable attention has been paid to Monascus-fermented products and secondary metabolites, due to their therapeutic effects on a variety of ailments. These secondary compounds include edible pigments, isoflavones, enzymes, fatty acids, organic acids, dimerumic acid (antioxidant), vitamins, $\gamma$-aminobutyric acid (GABA, hypotensive agent), monacolin K (lovastatin, anti-hypercholesterolemic agent), and other active components.

According to the Food and Drug Administration (FDA), "a new dietary ingredient is a dietary ingredient that was not marketed in the United States in a dietary supplement before 15 October 1994" [54]. However, no list of the dietary supplements on the market, or on the market as dietary supplements before 15 October 1994, exists. There is no way for the industry to verify this timestamp. Despite the fact that a variety of bio-functional secondary metabolites are produced by Monascus, the only Monascus sp. product that is commercially marketed and approved by the FDA's Federal Food, Drug, and Cosmetic Act is Monascus 8000F [54]. The FDA announced the "New Dietary Ingredients Used in Dietary Supplements" in August 2016, which states, "Probiotics and other 
microbial ingredients do not constitute a distinct category of dietary ingredient" [6]. The document also states that algae and fungi do not fall into the category of microbial ingredients. Although this is not yet legally binding information, many hurdles to the production and application of fungi can be expected as a result of this FDA statute. The corresponding research investigations into exactly how certain strains accurately produce secondary metabolites, and how the produced secondary metabolites are biologically converted, are prioritized projects in the edible molds field, as well as other microbial studies (e.g., Lactobacillus sp. and Bifidobacterium sp.) [55]. Because the functional materials produced by the Monascus strain are distinct, and the pigment activity depends on the growth mode, numerous research fields would benefit from the Monascus applications currently in development [56]. For instance, various biocatalyzed Monascus pigments obtained from Monascus sp. KCCM 10093 fermentation were combined with supplements, and tested to observe their functional effects. The functional effects of KCCM 10093 derivatives produced from fermented pigments include obesity inhibitory activity [57], cholesteryl ester transfer protein (CETP) inhibitory activity [58], hepatitis $C$ virus replication inhibition [59], diet-related lipase and $\alpha$-glucosidase inhibitory activities [60], anti-atherosclerosis effects [20], antibacterial activity [61,62], and photo-stability [22,23,37]. Although several studies have reported the amino acid or amine derivatives of Monascus sp. KCCM 10093 pigments and their benefits, to the best of our knowledge there is no existing review of these studies. The main purpose of this review is to summarize our current understanding of KCCM 10093 fermented byproducts (mainly derivative compounds), their valuable natural effects, and their potential industrial applications.

\section{Antimicrobial and Antiviral Effects of Monascus Pigment Derivatives}

Monascus pigment products are produced via solid state fermentation (SSF), and the inoculation of the seed culture (the dry form of Monascus) onto specific solid substrates, such as agar medium, bread, rice bran, cassava, apple, pomace, and wheat [36,63-65]. Enhanced pigment and other secondary metabolite production is achieved with the supplementation of other compounds, such as amino acids, amines, amino sugars, amino alcohols, nitrogen compounds, nucleic acids, chitosan, and co-culture with either a Saccharomyces cerevisiae or Aspergillus oryzae strain [24,66]. Interestingly, the co-culture with one of these strains in the solid medium caused remarkable morphological changes in Monascus cells. This is possibly due to the production of hydrolytic enzymes (such as $\alpha$-amylase and chininase) from either from S. cerevisiae or A. oryzae. These enzymes could damage the cell walls of Monascus, and induce the cells to produce more hydrophobic molecules (e.g., pigments) as a mechanism to protect themselves from hydrolytic enzymes [24]. When Monascus is cultured with supplementary molecules, the pigments' oxygen group can be substituted by supplements, which may benefit the generation of synthesized, value-added biomolecules (Figure 2) [20].

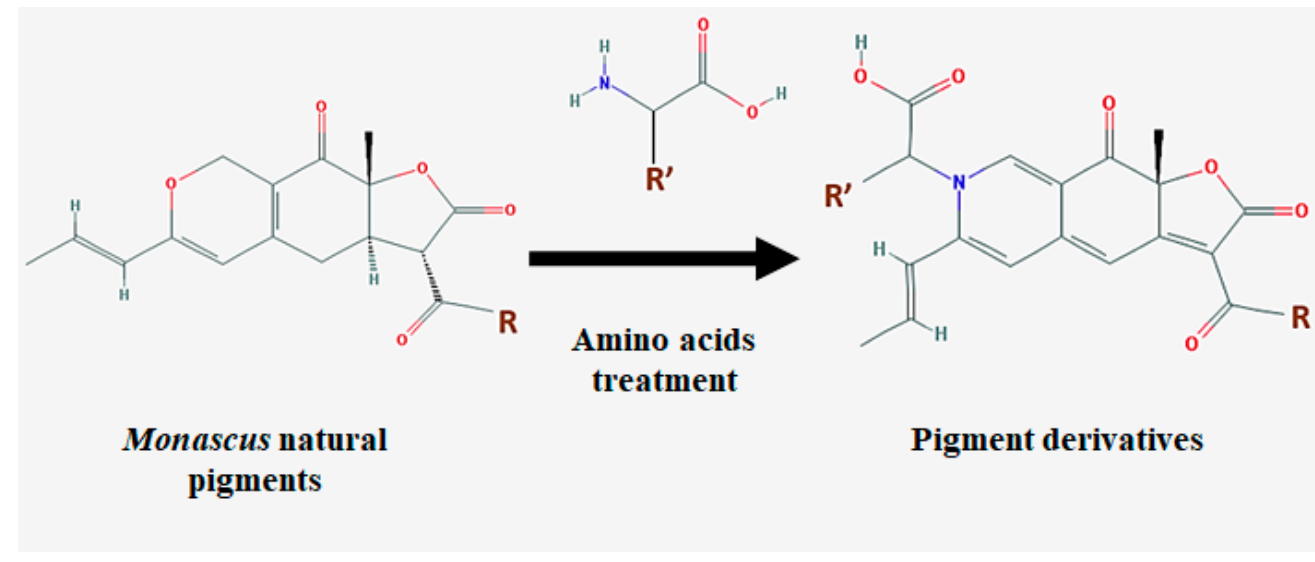

Figure 2. Substitution of Monascus pigments' oxygen moiety for amino acids' nitrogen moiety. $\mathrm{R}=\mathrm{C}_{5} \mathrm{H}_{11}$ or $\mathrm{C}_{7} \mathrm{H}_{15}$. $\mathrm{R}^{\prime}$ is a functional group of amino acids. 
The cultivation protocol for derivative synthesis is as follows: (1) slant agar culture, (2) seed culture, (3) inoculation of seed culture, (4) main cultivation with supplements, (5) isolation, and (6) drying. Youngsmith $[16,17,67]$ reported that the synthesis of Monascus pigments and metabolites can be determined by the Monascus growth. Since fungi consume energy sources (carbon and nitrogen) from growth substrates during the initial stage, the synthesis of secondary compounds depends upon their growth conditions. This indicates that the substrate composition and the management of fungal growth are major indicators of desirable byproduct production.

The recent use of non-chemical preservatives, minimally-processed materials, and natural food ingredients are crucial consumer demands, to avoid the toxicological issues related with artificial food antimicrobials [68-70]. Monascus pigments and their derivatives have been utilized in food coloring and traditional additives; some have even been studied and applied in food industries. The antimicrobial activity of fermented pigments has a promising potential for food alternatives, since these compounds are practically natural and free from chemical synthesis. Monascus pigments fermented by Monascus ruber CCT 3802 [28,32,36], Monascus purpureus [71], Monascus purpureus N11S [72], and Monascus M3428 [73] were examined to investigate if they demonstrate antimicrobial activity in response to Escherichia coli, Salmonella enteritidis, Bacillus subtilis, staphylococcus aureus, and yeast, respectively. Additional studies on the antimicrobial effects of Monascus fermentation reported that gram-positive bacteria are more susceptible to inhibition than gram-negative bacteria, and Latobacillus' resistance is negligible [74-76]. This result encouraged the use of a Monascus pigment as a replacement for nitrite in meat production [77]. The specific mechanisms and properties of this finding are still unknown; however, the finding suggests that antimicrobial activity is significantly determined by cell growth conditions and culture medium compositions [72,73,78].

Kim et al. [61] found that the antimicrobial activity of the red pigments produced from KCCM 10093 fermentation produced poor responses to gram-positive bacteria, gram-negative bacteria, and filamentous fungi. However, these pigment derivatives (which were cultivated with amino acids) displayed dramatically improved antimicrobial activities during minimum inhibitory concentration (MIC) tests. The amino acid derivatives containing a phenyl group demonstrated strong antimicrobial activities. Further testing of Phe and Tyr derivatives (with a phenyl ring) presented higher activity (MIC: 4-16 $\mu \mathrm{g} / \mathrm{mL}$ ) than the orange pigment (MIC: 10-30 $\mu \mathrm{g} / \mathrm{mL}$ ) [71,79] and the red pigment (MIC > $32 \mu \mathrm{g} / \mathrm{mL}$ ), which was mainly due to the hydrophobicity and absorption of the pigment derivatives. These pigment derivatives may affect cell morphology by aggregating the cells, which results in suppressed cell growth, due to inhibited oxygen transfer and nourishment [61]. Additional studies reported $[80,81]$ that chitosan had antimicrobial activities, via binding or forming cell pellets, which resulted in a lack of oxygen transfer. It is worth noting that chitosan's antimicrobial activities were only effective with gram-negative bacteria and yeast with high MIC values (MIC: $100-10,000 \mu \mathrm{g} / \mathrm{mL})$.

Chronic liver disease caused by the hepatitis $\mathrm{C}$ virus $(\mathrm{HCV})$ is a global health concern. More than 170 million HCV infections may result in HCV-related diseases, including chronic hepatitis and hepatocellular carcinoma [82,83]. Many studies have investigated HCV infection prevention, such as the tests with pegylated interferon (IFN) and ribavirin (a nucleoside analogue) developed for clinical trials. However, further research and other anti-HCV drugs are required, due to the side effects from the use of IFN- $\alpha$ and ribavirin, as well as low virological sensitivity $(<50 \%$ for HCV genotype 1 or 4) [84]. Since the HCV NS5B RNA-dependent RNA polymerase (RdRp) enzyme is considered a key enzyme of HCV replication, the inhibition or deactivation of this enzyme is an effective strategy against viral replication. Sun et al. [59] have identified that Monascus pigment derivatives from KCCM 10093 demonstrate antiviral activity that could remarkably suppress HCV RNA replication. In the Huh7 human hepatoma cell line, six major orange pigment derivative incubations at $10 \mu \mathrm{M}$ inhibited HCV RNA levels by 38-53\%. The positive control (standard HCV therapy) of IFN- $\alpha$ (100 IU/mL) decreased the HCV level by 75\%. Further tests with the combination of screened Monascus pigment derivatives (Phe, Val, and Leu) and IFN- $\alpha$ increased the inhibition levels by 
up to $88 \%$, and the Leu derivative demonstrated the most effective anti-HCV activity. HCV RNA inhibition via this combination treatment was dose-dependent, with an $\mathrm{IC}_{50}$ value of $8.9 \mu \mathrm{M}$, which did not affect cell viability at dose concentrations up to $50 \mu \mathrm{M}$ (no cytotoxicity). The HCV inhibition mechanism is not yet clearly identified; however, further studies on HCV RNA replication suggested that Monascus pigment derivatives blocked the cholesterol biosynthetic steps of mevalonate, as well as 3-hydroxy-3-methyglutaryl coenzyme A (HMG-CoA) reductase, which are important intermediate compounds that synthesize cholesterol as an end product. In addition, the antiviral activity of Monascus pigment derivatives was verified with other types of HCV (genotypes $2 a$ and $1 b$ ), which could offer potential alternatives to current $\mathrm{HCV}$ therapies and antiviral drugs.

\section{Regulation of Cholesterol Synthesis and Anti-Obesity Effects}

Atherosclerosis-the buildup of oxidized cholesterol, fat, calcium, waste products, and other molecular substances in the arteries-is a significant disease worldwide. It is reported that atherosclerosis accounts for around $32 \%$ of deaths in the U.S. $[85,86]$. As undesirable molecules build up, also called plaque, the diameter of the artery declines, and the arterial walls thicken, which constricts the supply of oxygen and oxygen-rich blood to organs and cells throughout the body. Furthermore, plaque can accumulate in other arteries throughout the body (i.e., the heart, muscle, brain, leg, and kidney). Blood clots caused by plaque may travel to another part of the body and inhibit blood flow as well. These plaque deposits cause different atherosclerosis-related diseases, including coronary heart disease, coronary microvascular disease, stroke, carotid artery disease (plaque in the neck arteries), peripheral artery disease (plaque in the arteries of the legs, arms, and pelvis), and chronic kidney disease $[87,88]$. Decreasing low-density lipoprotein cholesterol (LDL-C) or increasing high-density lipoprotein cholesterol (HDL-C) can prevent atherosclerotic diseases [89-91]. Cholesteryl ester transfer protein (CETP) is the main molecule that transfers cholesteryl esters (CEs) and triglycerides (TGs) from HDL to TG lipoproteins, which contributes to not only increased LDL levels, but also reduced HDL levels $[92,93]$. The inhibition of CETP is one of the most effective approaches to manage the cholesterol levels of the body. Jang et al. [58] reported that amino acid derivatives of KCCM 10093-fermented pigments had an inhibitory effect on CETP. Their study showed that 19 different amino derivatives were generated from the fermentations of orange pigments (monascorubrin and rubropunctatin) and L-amino acids. Initial CETP inhibition testing of the 19 derivatives at $0.5 \mu \mathrm{M}$ treatment showed that 14 of the derivatives had inhibitory activities. Among them, L-Thr and L-Tyr derivatives displayed the highest CETP inhibitions of $20 \%$ and $13 \%$, respectively. The amino acid is strongly related to CETP inhibition. The amino acid phenyl structure is essential to inhibition. During further tests of these compounds, ranging from $0.2-2 \mu \mathrm{M}$, CETP inhibitions were observed of up to $55 \%$ with L-Thr, and $44 \%$ with L-Tyr derivatives at $2 \mu \mathrm{M}$, respectively, suggesting that a high dose of these derivatives increases the CETP inhibition level. The $\mathrm{IC}_{50}$ values of $\mathrm{L}-\mathrm{Thr}$ and $\mathrm{L}-\mathrm{Tyr}$ derivatives were estimated to be about $1.0 \mu \mathrm{M}$ and $2.3 \mu \mathrm{M}$, respectively.

Some drugs are prescribed to reduce atherosclerosis, such as torcetrapib (against hypercholesterolemia), anacetrapib (to treat hypercholesterolemia), and evacetrapib (to inhibit CETP). These chemical drugs have $\mathrm{IC}_{50}$ values of $5-50 \mathrm{nM}$, and lead to decreased LDL-C (15-40\%) and increased HDL-C (55-140\%) [94-96]. Other findings described that natural molecules from fruits have CETP-inhibitory activities; for instance, polyphenols from apples and grapes $\left(\mathrm{IC}_{50}\right.$ at $\left.100 \mathrm{mM}\right)$ and xanthohumol ( $\mathrm{IC}_{50}$ at $\left.88 \mu \mathrm{M}\right)$ [97-99]. While the $\mathrm{IC}_{50}$ values of the L-Thr and L-Tyr derivatives were lower than the drug values, these natural compounds could be proposed as alternatives to synthetic medications. Furthermore, the chemical drugs used in clinical treatment have toxicity problems. Monascus-fermented derivatives are natural molecules, and considerably less toxic [96,100].

Cholesterol biosynthesis is the result of transferring acetyl-CoA to cytosol. 3-hydroxy-3methyglutaryl coenzyme A (HMG-CoA) reductase is a key enzyme, able to convert HMG-CoA to mevalonate, and consequently increase cholesterol levels [101,102]. Several studies have addressed that the inhibition of HMG-CoA reductase could reduce cholesterol levels in the human body. Moreover, 
a number of commercial drug clinical trials (i.e., Lovastatin, Monacolin K, and other HMG-CoA inhibitors) regulate the elevated cholesterol levels caused by hypercholesterolemia [103-105]. Monascus pigment derivatives produced from KCCM 10093 have been reported to hamper HMG-CoA reductase, and further anti-cholesterol tests were performed in vivo using mice [20]. Among the 13 amino acid derivatives that were developed, the Thr-derivative had the highest HMG-CoA inhibition at 35\%, similar to the orange pigment (36\%). The oxygen moiety of the pigment is susceptible to substitution from the nitrogen moiety in the supplemented amino acid during fermentation. The oxygen moiety of the orange pigment and its derivatives can increase HMG-CoA reductase inhibition, by biding onto the enzymes. Similar to the findings of previous works $[57,60]$, the phenyl groups (aromatic, hydrophobic, and non-polar aliphatic) of Monascus pigment derivatives correlated to enzyme inhibitions. Further diet effect tests in vivo presented that the control group (diet medium $+2 \%(w / w)$ cholesterol) increased mice weight by $27-51 \%$, while the supplementation of $0.01 \%$ orange pigment (g pigment/g mouse weight) or $0.02 \%$ Thr-derivative ( $\mathrm{g} / \mathrm{g}$ mouse weight) in similar experimental conditions did not affect weight changes in mice. In addition, feeding cholesterol to the mice increased HDL and LDL by $41 \%$ (from 38.6 to $54.5 \mathrm{mg} / \mathrm{dL}$ ) and $110 \%$ (from 47.2 to $99.2 \mathrm{mg} / \mathrm{dL}$ ), respectively. The Thr-derivative increased HDL by $1-9 \%$, and decreased LDL by $28-26 \%$. These results suggested that the orange pigment and the Thr-derivative have anti-atherosclerosis effects, and could be considered as natural alternatives used in clinical trials.

Overweight and obese conditions often lead to various chronic diseases, and can increase the risk of obesity-related diseases such as high blood pressure (hypertension), dyslipidemia, coronary heart disease, stroke, gallbladder disease, osteoarthritis, mental disorders (clinical depression, anxiety, and depression), cancers (colon, liver, kidney, breast, and endometrial), and sleep and breathing problems [106]. The medical care cost of obesity and obesity-related diseases was estimated to be about $\$ 147$ billion USD in 2008. Worldwide, \$3.38 billion USD (\$79 per obese individual) and $\$ 6.38$ billion USD (\$132 per obese individual) has been spent on obesity and obesity-related diseases, respectively, and these costs are increasing [106,107].

Choe et al. [57] found that amine derivatives of Monascus pigments demonstrated anti-obesity activities both in vivo (3T3-L1 preadipocyte mouse cells) and in vitro (C57BL/6 mice). Monascus pigments were initially produced via KCCM 10093 fermentation, and the isolated orange pigments were serially synthesized with 47 different amines. Among the 47 different amine derivatives, 16 derivative compounds were confirmed to have an inhibitory effect on adipogenic differentiation in 3T3-L1 cells. In particular, 4-phenylburylamine (PBA) and 2-( $p$-toyly) ethylamine (TEA) showed the best results, with about $40 \%$ reduction of cell differentiations at $2.5 \mu \mathrm{M}$ and $12.5 \mu \mathrm{M}$ concentrations, respectively, compared to the control test without derivatives (Figure 3A) [57]. To better understand these inhibitory effects, further testing of PBA and TEA derivatives was conducted on the adipogenic transcriptional factors (PPAR $\gamma$ and $\mathrm{C} / \mathrm{EBP} \alpha)$. As the concentrations of the PBA and TEA derivatives increased, the expression levels of PPAR $\gamma$ and $\mathrm{C} / \mathrm{EBP} \alpha$ decreased. For PPAR $\gamma, 70 \%$ and $80 \%$ inhibition was observed with treatments of PBA $(12.5 \mu \mathrm{M})$ and TEA $(10 \mu \mathrm{M})$ derivatives, respectively (Figure 3B) [57].

$\mathrm{C} / \mathrm{EBP} \alpha$ tests, with similar PBA and TEA derivative concentrations and experimental conditions, resulted in $70 \%$ transcriptional inhibition. In additional in vivo tests, mice were fed PBA and TEA derivatives at different feeding concentrations for 16 weeks, to examine the effects of derivatives on weight gain, epididymal adipose tissue (EAT), and liver tissue. The supplementation of derivatives at 0.1-0.4 mg/g mouse per day to the high-fat diet (HFD) group remarkably decreased the weight gain by 26.8-59.5\%, compared with the results from the HFD group without the derivative supplements. The increase of derivative concentrations caused a consistent pattern of inhibitory effects and decreased weight gain. TEA derivatives of $0.4 \mathrm{mg} / \mathrm{g}$ mouse per day showed the lowest weight gain of $59.5 \%$. Similarly, decreased EAT and liver tissue weights were observed with the derivatives; TEA derivatives of 0.2 and $0.4 \mathrm{mg} / \mathrm{g}$ mouse per day reduced EAT weight and liver tissue weight by $56 \%$ and $9.8 \%$, respectively. These results indicate that amine derivatives of Monascus pigments 
have valuable anti-obesity effects. The exact mechanisms and activities of derivatives should be examined through future research. These previous works may suggest that the phenyl group of amine derivatives, a cyclic atom ring functional group, plays a key role in hindering the differentiation of plaque cells. Some studies have concurred with these results, and offered evidence that phenolic compounds-flavonoids, genistein, naringenin, rutin, EGCG, and curcumin-could contribute toward the inhibition of 3T3-L1 cell differentiation and adipogenic transcriptional factors [108-111].

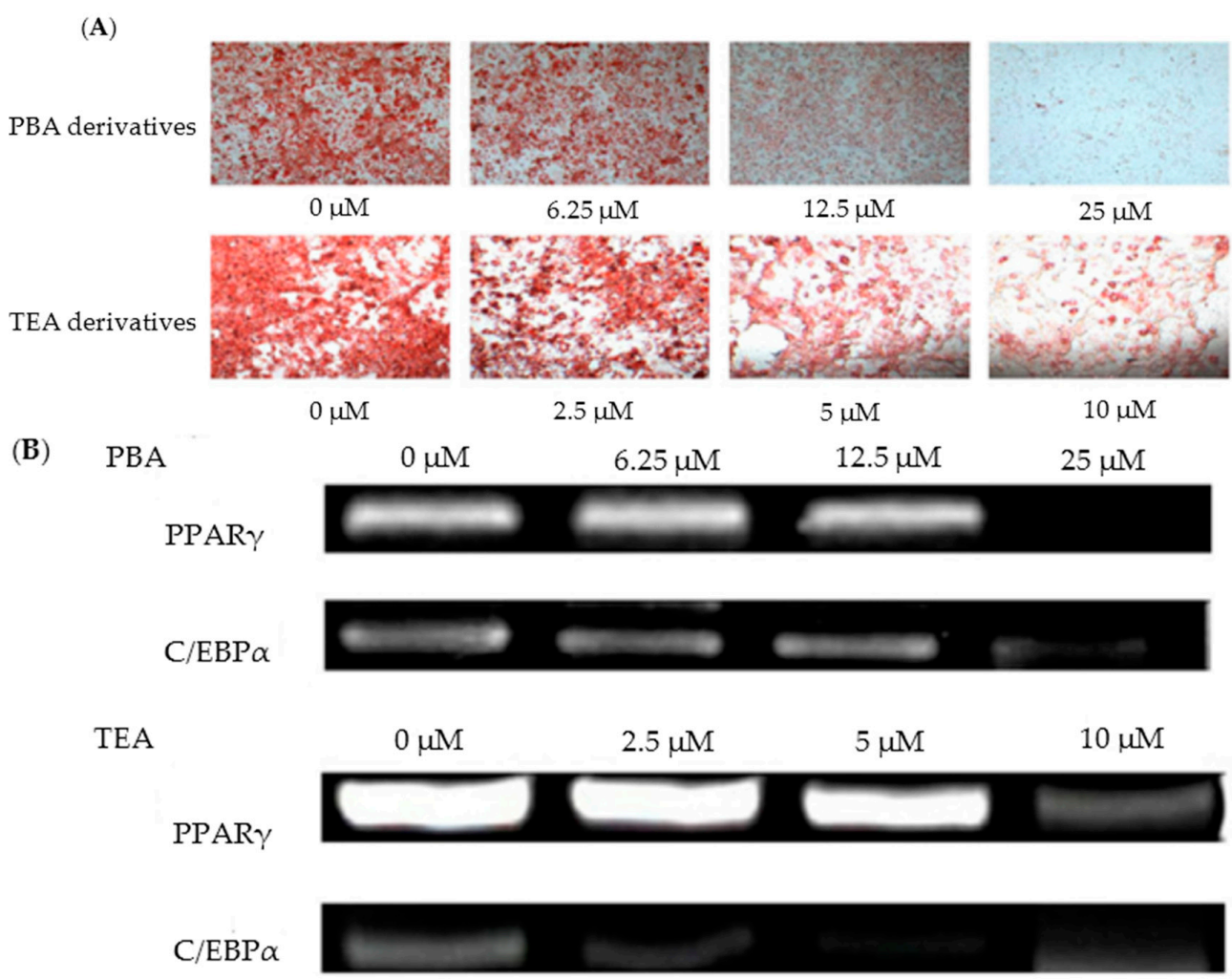

Figure 3. (A) Lipid cells treated with varied levels of amine derivatives (dyed with oil red O); (B) Inhibited adipogenic transcriptional factors (PPAR $\gamma$ and $C / E B P \alpha)$, with various amine derivative concentrations (adopted and modified from Choe et al. [57]).

\section{Conclusions and Research Outlook}

Based on the previous literature reviewed herein, Monascus pigments and their derivatives demonstrate promising potential in various applications: (1) color agents and food additives, (2) antimicrobials, (3) anti-virologicals, (4) anti-obesity, and (5) cholesterol regulation. The food preservative effect of Monascus pigments has been scientifically confirmed. Moreover, a commercial dietary product (Monacolin by Maruzen Pharmaceuticals) containing Monascus extract has been introduced in Japan [76]. As the interest in and applications of Monascus metabolites have grown, concerns regarding their potential toxicity and safe consumption have also increased. Citrinin, the dominant mycotoxin produced by Monascus, is able to contaminate Monascus' secondary metabolites. Sabater-Vilar et al. [14] identified the citrinin in commercial Monascus samples, with concentration levels of 0.2-1.71 ug/g. Citrinin may cause organ damage in the liver, kidney, and organ tissues, and has been evaluated as a carcinogenic compound [13,112]. The production and toxicity of citrinin are highly relative to strain, media, carbon and nitrogen concentration, and temperature $[21,72,113,114]$. In response to the toxicity and safety issues, the maximum citrinin allowed in food supplements (based on red yeast Monascus) in Japan is $200 \mathrm{ng} / \mathrm{g}$, and in the European Union the maximum is $2 \mathrm{mg} / \mathrm{kg}[115,116]$. To the best of our knowledge, there is no research on safety, fungal toxin, and negative health effects of Monascus sp. KCCM 10093. Therefore, future 
studies should explore ways to experiment with lower levels of these possibly toxic compounds, and produce high-quality secondary metabolites via optimal fermentation processes. Other research groups have paid attention the biological activities of Monascus pigments for applications in iatrical treatments and cancer prevention. Monascus-fermented products have proven effective in a number of such therapies. Lee et al. [117] confirmed that ethanol extract from red mold rice (RMRE) was beneficial to Alzheimer's disease prevention. Some works indicated that red mold rice and dioscorea exhibit anti-cancer activities in the skin [118], liver [119], colon [120,121], lungs [122,123], and mouth [124-126]. Along with these clinical evaluations of Monascus pigments and metabolites, further studies of its molecular biology began in the early 2000s. Molecular techniques for the transformation of Monascus include electroporation [127,128], polyethylene glycol-mediated transformation (PEG-MPT) [129], and restricted-enzyme mediated integration (REMI) [130]. In order to understand the key secondary metabolic steps in Monascus fermentation, specific genes for pigments, citrinin, G-protein, and monacolin $\mathrm{K}$ were examined and analyzed [131-136]. Although these genetic tools could facilitate our understanding of Monascus, the metabolite synthesis and biochemical pathway processes remain unclear. There are unknown novel ingredients and salutary effects of Monascus metabolites. Further investigation of Monascus, providing taxonomic comparison, phylogenetic analysis, and morphological and physiological properties, will improve its efficacy in therapeutic and food-based applications.

Acknowledgments: This work was supported by Middle Tennessee State University Research Program in 2017 (faculty start-up fund). The authors wish to thank Tony V. Johnston of Middle Tennessee State University and Lauren B. Mallett of Purdue University for her review and feedback on this paper. All authors would also like to thank Michael R. Ladisch and Eduardo Ximenes of Purdue University for their support of Daehwan Kim and Seockmo Ku.

Author Contributions: Daehwan Kim and Seockmo Ku performed the literature research and co-wrote the review. The two authors discussed the drafts and approved the final manuscript for publication.

Conflicts of Interest: The authors declare no conflict of interest.

\section{Abbreviation}

FDA Food and Drug Administration

\section{References}

1. Burchi, F.; Fanzo, J.; Frison, E. The role of food and nutrition system approaches in tackling hidden hunger. Int. J. Environ. Res. Public Health 2011, 8, 358-373. [CrossRef] [PubMed]

2. Younesi, E.; Ayseli, M.T. An integrated systems-based model for substantiation of health claims in functional food development. Trends Food Sci. Technol. 2015, 41, 95-100. [CrossRef]

3. Ku, S. Finding and Producing Probiotic Glycosylases for the Biocatalysis of Ginsenosides: A Mini Review. Molecules 2016, 21, 645. [CrossRef] [PubMed]

4. Ku, S.; Park, M.S.; Ji, G.E.; You, H.J. Review on bifidobacterium bifidum bgn4: Functionality and nutraceutical applications as a probiotic microorganism. Int. J. Mol. Sci. 2016, 17, 1544. [CrossRef] [PubMed]

5. Functional Foods Market is Expected to Drive Growth due to Awareness towards Changing Lifestyle, Health and Proper Diet Till 2024: Grand View Research, Inc. Available online: http:/ / www.abnewswire. $\mathrm{com} /$ pressreleases / functional-foods-market-is-expected-to-drive-growth-due-to-awareness-towardschanging-lifestyle-health-and-proper-diet-till-2024-grand-view-research-inc_133119.html (accessed on 26 September 2017).

6. Functional Foods Market is Expected to Reach $\$ 255.10$ Billion by 2024. Available online: http://www. grandviewresearch.com/press-release/global-functional-foods-market (accessed on 26 September 2017).

7. Li, Y.; Ku, S.; Park, M.S.; Li, Z.; Ji, G.E. Acceleration of Aglycone isoflavones and $\gamma$-Aminobutyric Acid Production from Doenjang using Whole cell Biocatalysis Accompanied by Protease Treatment. J. Microbiol. Biotechnol. 2017, 27, 1952-1960. [CrossRef] [PubMed]

8. Carels, M.; Shepherd, D. The effect of different nitrogen sources on pigment production and sporulation of Monascus species in submerged, shaken culture. Can. J. Microbiol. 1977, 23, 1360-1372. [CrossRef] [PubMed] 
9. Lin, C.F.; Iizuka, H. Production of Extracellular Pigment by a Mutant of Monascus kaoliang sp. nov. Appl. Environ. Microbiol. 1982, 43, 671-676. [PubMed]

10. Nout, M.J.R.; Aidoo, K.E. Asian Fungal Fermented Food. Ind. Appl. 2002, 10, 23-47.

11. Shi, Y.C.; Pan, T.M. Beneficial effects of Monascus purpureus NTU 568-fermented products: A review. Appl. Microbiol. Biotechnol. 2011, 90, 1207-1217. [CrossRef] [PubMed]

12. Chen, W.; He, Y.; Zhou, Y.; Shao, Y.; Feng, Y.; Li, M.; Chen, F. Edible Filamentous Fungi from the Species Monascus: Early Traditional Fermentations, Modern Molecular Biology, and Future Genomics. Compr. Rev. Food Sci. Food Saf. 2015, 14, 555-567. [CrossRef]

13. Blanc, P.J.; Loret, M.O.; Goma, G.; Rangueil, C.S. De Production of citrinin by various species of Monascus. Biotechnol. Lett. 1995, 17, 291-294. [CrossRef]

14. Sabater-Vilar, M.; Maas, R.F.M.; Fink-Gremmels, J. Mutagenicity of commercial Monascus fermentation products and the role of citrinin contamination. Mutat. Res. Genet. Toxicol. Environ. Mutagen. 1999, 444, 7-16. [CrossRef]

15. Vendruscolo, F.; Bühler, R.M.M.; De Carvalho, J.C.; De Oliveira, D.; Moritz, D.E.; Schmidell, W.; Ninow, J.L. Monascus: A Reality on the production and application of microbial pigments. Appl. Biochem. Biotechnol. 2016, 178, 211-223. [CrossRef] [PubMed]

16. Yongsmith, B.; Kitprechavanich, V.; Chitradon, L.; Chaisrisook, C.; Budda, N. Color mutants of Monascus sp. KB9 and their comparative glucoamylases on rice solid culture. J. Mol. Catal. B Enzym. 2000, 10, $263-272$. [CrossRef]

17. Yongsmith, B.; Krairak, S.; Bavavoda, R. Production of yellow pigments in submerged culture of a mutant of Monascus spp. J. Ferment. Bioeng. 1994, 78, 223-228. [CrossRef]

18. Jongrungruangchok, S.; Kittakoop, P.; Yongsmith, B.; Bavovada, R.; Tanasupawat, S.; Lartpornmatulee, N.; Thebtaranonth, Y. Azaphilone pigments from a yellow mutant of the fungus Monascus kaoliang. Phytochemistry 2004, 65, 2569-2575. [CrossRef] [PubMed]

19. Chen, W.; Chen, R.; Liu, Q.; He, Y.; He, K.; Ding, X.; Kang, L.; Guo, X.; Xie, N.; Zhou, Y.; et al. Orange, Red, Yellow: Biosynthesis of azaphilone pigments in Monascus fungi. Chem. Sci. 2017, 8, 4917-4925. [CrossRef] [PubMed]

20. Jeun, J.; Jung, H.; Kim, J.H.; Kim, Y.O.; Youn, S.H.; Shin, C.S. Effect of the Monascus pigment threonine derivative on regulation of the cholesterol level in mice. Food Chem. 2008, 107, 1078-1085. [CrossRef]

21. Hajjaj, H.; Blanc, P.; Groussac, E. Kinetic analysis of red pigment and citrinin production by Monascus ruber as a function of organic acid accumulation. Enzyme Microb. Technol. 2000, 27, 619-625. [CrossRef]

22. Jung, H.; Kim, C.; Kim, K.; Shin, C.S. Color characteristics of Monascus pigments derived by fermentation with various amino acids. J. Agric. Food Chem. 2003, 51, 1302-1306. [CrossRef] [PubMed]

23. Jung, H.; Kim, C.; Shin, C.S. Enhanced photostability of Monascus pigments derived with various amino acids via fermentation. J. Agric. Food Chem. 2005, 53, 7108-7114. [CrossRef] [PubMed]

24. Shin, C.S.; Kim, H.J.; Kim, M.J.; Ju, J.Y. Morphological change and enhanced pigment production of Monascus when cocultured with Saccharomyces cerevisiae or Aspergillus oryzae. Biotechnol. Bioeng. 1998, 59, 576-581. [CrossRef]

25. Ju, J.Y.; Kim, D.Y.; Suh, J.H.; Shin, C.S. Optimization of Monascus red pigment fermentation by regulating chitinase activity level in fermentor. Bioprocess. Eng. 1999, 21, 25-29. [CrossRef]

26. Kim, H.J.; Kim, J.H.; Oh, H.J.; Shin, C.S. Morphology control of Monascus cells and scale-up of pigment fermentation. Process Biochem. 2002, 38, 649-655. [CrossRef]

27. De Carvalho, J.C.; Oishi, B.O.; Pandey, A.; Soccol, C.R. Biopigments from Monascus: Strains selection, citrinin production and color stability. Braz. Arch. Biol. Technol. 2005, 48, 885-894. [CrossRef]

28. Meinicke, R.M.; Vendruscolo, F.; Esteves Moritz, D.; de Oliveira, D.; Schmidell, W.; Samohyl, R.W.; Ninow, J.L. Potential use of glycerol as substrate for the production of red pigments by Monascus ruber in submerged fermentation. Biocatal. Agric. Biotechnol. 2012, 1, 238-242. [CrossRef]

29. Babitha, S.; Soccol, C.R.; Pandey, A. Jackfruit seed for production of Monascus pigments. Food Technol. Biotechnol. 2006, 44, 465-471.

30. Babitha, S.; Soccol, C.R.; Pandey, A. Solid-state fermentation for the production of Monascus pigments from jackfruit seed. Bioresour. Technol. 2007, 98, 1554-1560. [CrossRef] [PubMed]

31. Pastrana, L.; Goma, G. Estimation of bioprocess variables from Monascus ruber cultures by means of stoichiometric models. Process Biochem. 1995, 30, 607-613. [CrossRef] 
32. Vendruscolo, F.; Rossi, M.J.; Schmidell, W.; Ninow, J.L. Determination of oxygen solubility in liquid media. ISRN Chem. Eng. 2012, 2012, 1-5. [CrossRef]

33. Chen, M.H.; Johns, M.R. Effect of $\mathrm{pH}$ and nitrogen source on pigment production by Monascus purpureus. Appl. Microbiol. Biotechnol. 1993, 40, 132-138. [CrossRef]

34. Orozco, S.F.B.; Kilikian, B.V. Effect of $\mathrm{pH}$ on citrinin and red pigments production by Monascus purpureus CCT3802. World J. Microbiol. Biotechnol. 2008, 24, 263-268. [CrossRef]

35. Ahn, J.; Jung, J.; Hyung, W.; Haam, S.; Shin, C. Enhancement of Monascus pigment production by the culture of Monascus sp. J101 at low temperature. Biotechnol. Prog. 2006, 22, 338-340. [CrossRef] [PubMed]

36. Vendruscolo, F.; Pitol, L.O.; Carciofi, B.A.M.; Moritz, D.E.; Laurindo, J.B.; Schmidell, W.; Ninow, J.L. Construction and application a vane system in a rotational rheometer for determination of the rheological properties of Monascus ruber CCT 3802. J. Biorheol. 2010, 24, 29-35. [CrossRef]

37. Jung, H.; Choe, D.; Nam, K.Y.; Cho, K.H.; Shin, C.S. Degradation patterns and stability predictions of the original reds and amino acid derivatives of Monascus pigments. Eur. Food Res. Technol. 2011, 232, 621-629. [CrossRef]

38. Krairak, S.; Yamamura, K.; Irie, R.; Nakajima, M.; Shimizu, H.; Chim-Anage, P.; Yongsmith, B.; Shioya, S. Maximizing yellow pigment production in fed-batch culture of Monascus sp. J. Biosci. Bioeng. 2000, 90, 363-367. [CrossRef]

39. Carels, M.; Shepherd, D. Sexual reproductive cycle of Monascus in submerged shaken culture. J. Bacteriol. 1975, 122, 288-294. [PubMed]

40. Ju, J.Y.; Shin, C.S.; Whitcombe, M.J.; Vulfson, E.N. Imprinted polymers as tools for the recovery of secondary metabolites produced by fermentation. Biotechnol. Bioeng. 1999, 64, 232-239. [CrossRef]

41. Lee, Y.-K.; Chen, D.-C.; Chauvatcharin, S.; Seki, T.; Yoshida, T. Monascus of pigments by a solid-liquid culture method. J. Ferment. Bioeng. 1995, 79, 516-518. [CrossRef]

42. Lin, T.F.; Yakushijin, K.; Büchi, G.H.; Demain, A.L. Formation of water-soluble Monascus red pigments by biological and semi-synthetic processes. J. Ind. Microbiol. 1992, 9, 173-179. [CrossRef]

43. Stchigel, A.M.; Cano, J.F.; Abdullah, S.K.; Guarro, J. New and interesting species of Monascus from soil, with a key to the known species. Stud. Mycol. 2004, 50, 299-306.

44. Hawksworth, D.L.; Pitt, J.I. A new taxonomy for Monascus species based on cultural and microscopical characters. Aust. J. Bot. 1983, 31, 51-61. [CrossRef]

45. Hocking, A.D.; Pitt, J.I.; Mycologia, S.; Feb, N.J. Two new species of xerophilic fungi and a further record of eurotium halophilicum. Mycologia 2017, 80, 82-88. [CrossRef]

46. Cannon, P.F.; Abdullah, S.K.; Abbas, B.A. Two new species of Monascus from Iraq, with a key to known species of the genus. Mycol. Res. 1995, 99, 659-662. [CrossRef]

47. Lian, X.; Wang, C.; Guo, K. Identification of new red pigments produced by Monascus ruber. Dyes Pigments 2007, 73, 121-125. [CrossRef]

48. Hamano, P.S.; Orozco, S.F.B.; Kilikian, B.V. Concentration determination of extracellular and intracellular red pigments produced by Monascus sp. Braz. Arch. Biol. Technol. 2005, 48, 43-49. [CrossRef]

49. Dominguez-Espinosa, R.M.; Webb, C. Submerged fermentation in wheat substrates for production of Monascus pigments. World J. Microbiol. Biotechnol. 2003, 19, 329-336. [CrossRef]

50. Lopes, F.C.; Tichota, D.M.; Pereira, J.Q.; Segalin, J.; De Oliveira Rios, A.; Brandelli, A. Pigment production by filamentous fungi on agro-industrial byproducts: An eco-friendly alternative. Appl. Biochem. Biotechnol. 2013, 171, 616-625. [CrossRef] [PubMed]

51. Zlova, P.J.I.; Ezanka, T.I.; Martfnkov, L.; Krent, V. Long-chain fatty acids from Monascus purpureus. Phytochemistry 1996, 43, 151-153.

52. Jůlová, P.; Martínkková, L.; Lozinski, J.; Machek, F. Ethanol as substrate for pigment production by the fungus Monascus purpureus. Enzyme Microb. Technol. 1994, 16, 996-1001. [CrossRef]

53. Park, H.G.; Jong, S.C. Molecular characterization of Monascus strains based on the D1/D2 regions of LSU rRNA genes. Mycoscience 2003, 44, 25-32. [CrossRef]

54. New Dietary Ingredients in Dietary Supplements-Backgroud for Industry. Available online: https: / /www. fda.gov /Food/DietarySupplements/ucm109764.htm (accessed on 29 November 2017).

55. Kuhbacher, T. Bacterial and fungal microbiota in relation to probiotic therapy (VSL\#3) in pouchitis. Gut 2006, 55, 833-841. [PubMed] 
56. Velmurugan, P.; Hur, H.; Balachandar, V.; Kamala-Kannan, S.; Lee, K.J.; Lee, S.M.; Chae, J.C.; Shea, P.J.; Oh, B.T. Monascus pigment production by solid-state fermentation with corn cob substrate. J. Biosci. Bioeng. 2011, 112, 590-594. [CrossRef] [PubMed]

57. Choe, D.; Lee, J.; Woo, S.; Shin, C.S. Evaluation of the amine derivatives of Monascus pigment with anti-obesity activities. Food Chem. 2012, 134, 315-323. [CrossRef]

58. Jang, H.; Choe, D.; Shin, C.S. Novel derivatives of Monascus pigment having a high CETP inhibitory activity. Nat. Prod. Res. 2014, 28, 1427-1431. [CrossRef] [PubMed]

59. Sun, J.M.; Kim, S.J.; Kim, G.W.; Rhee, J.K.; Kim, N.D.; Jung, H.; Jeun, J.; Lee, S.H.; Han, S.H.; Shin, C.S.; et al. Inhibition of hepatitis $C$ virus replication by Monascus pigment derivatives that interfere with viral RNA polymerase activity and the mevalonate biosynthesis pathway. J. Antimicrob. Chemother. 2012, 67, 49-58. [CrossRef] [PubMed]

60. Kim, J.H.; Kim, H.J.; Park, H.W.; Youn, S.H.; Choi, D.Y.; Shin, C.S. Development of inhibitors against lipase and $\alpha$-glucosidase from derivatives of Monascus pigment. FEMS Microbiol. Lett. 2007, 276, 93-98. [CrossRef] [PubMed]

61. Kim, C.; Jung, H.; Kim, Y.O.; Shin, C.S. Antimicrobial activities of amino acid derivatives of Monascus pigments. FEMS Microbiol. Lett. 2006, 264, 117-124. [CrossRef] [PubMed]

62. Kim, C.; Jung, H.; Kim, J.H.; Shin, C.S. Effect of Monascus pigment derivatives on the electrophoretic mobility of bacteria, and the cell adsorption and antibacterial activities of pigments. Colloids Surf. B Biointerfaces 2006, 47, 153-159. [CrossRef] [PubMed]

63. Carvalho, J.C.; Pandey, A.; Babitha, S.; Soccol, C.R. Production of Monascus biopigments: An overview. Agro Food Ind. Hi-Tech 2003, 14, 37-42.

64. Fang, H.H.P.; Li, C.; Zhang, T. Acidophilic biohydrogen production from rice slurry. Int. J. Hydrogen Energy 2006, 31, 683-692. [CrossRef]

65. Vendruscolo, F.; Ninow, J.L. Apple pomace as a substrate for fungal chitosan production in an airlift bioreactor. Biocatal. Agric. Biotechnol. 2014, 3, 338-342. [CrossRef]

66. Francis, F.J. Less common natural colorants. Nat. Food Color. 1996, 2, 310-342.

67. Yongsmith, B.; Tabloka, W.; Yongmanitchai, W.; Bavavoda, R. Culture conditions for yellow pigment formation by Monascus sp. KB 10 grown on cassava medium. World J. Microbiol. Biotechnol. 1993, 9, 85-90. [CrossRef] [PubMed]

68. Hintz, T.; Matthews, K.K.; Di, R. Review: The use of plant antimicrobial compounds for food preservation. BioMed Res. Int. 2015, 2015, 1-12. [CrossRef] [PubMed]

69. Zink, D.L. The impact of consumer demands and trends on food processing. Emerg. Infect. Dis. 1997, 3, 467-469. [CrossRef] [PubMed]

70. Grunert, K.G. Future trends and consumer lifestyles with regard to meat consumption. Meat Sci. 2006, 74, 149-160. [CrossRef] [PubMed]

71. Juzlová, P.; Martínková, L.; Křen, V. Secondary metabolites of the fungus Monascus: A review. J. Ind. Microbiol. 1996, 16, 163-170. [CrossRef]

72. Wong, H.-C.; Koehler, P.E. Production and Isolation of an Antibiotic from Monascus purpureus and its Relationship to Pigment Production. J. Food Sci. 1981, 46, 589-592. [CrossRef]

73. $\mathrm{Xu}, \mathrm{W}$. Study on the liquid fermentation to produce Monascus pigment with corn starch and antibacteria. Adv. Mater. Res. 2011, 183-185, 1336-1340. [CrossRef]

74. Konuray, G.; Erginkaya, Z. Antimicrobial and antioxidant properties of pigments synthesized from microorganisms. In The Battle against Microbial Pathogens: Basic Science, Technological Advances and Educational Programs; Méndez-Vilas, A., Ed.; Formatex Research Center: Badajoz, Spain, 2015; pp. 27-32.

75. Fabre, C.E.; Santerre, A.L.; Baberian, R.; Pareilleux, A.; Goma, G.; Blanc, P.J. Production and Food Applications of the Red Pigments of Monascus ruber. J. Food Sci. 1993, 58, 1099-1102. [CrossRef]

76. Erdoğrul, Ö.; Sebile, A. Review of the studies on the red yeast rice (Monascus purpureus). Turk. Electron. J. Biotechnol. 2004, 2, 37-49.

77. Yu, X.; Wu, H.; Zhang, J. Effect of Monascus as a nitrite substitute on color, lipid oxidation, and proteolysis of fermented meat mince. Food Sci. Biotechnol. 2015, 24, 575-581. [CrossRef]

78. Narsing Rao, M.P.; Xiao, M.; Li, W.J. Fungal and bacterial pigments: Secondary metabolites with wide applications. Front. Microbiol. 2017, 8, 1-13. [CrossRef] [PubMed] 
79. Martínková, L.; Jzlová, P.; Veselý, D. Biological activity of polyketide pigments produced by the fungus Monascus. J. Appl. Microbiol. 1995, 79, 609-616.

80. Rhoades, J.; Roller, S. Antimicrobial actions of degraded and native chitosan against spoilage organisms in laboratory media and foods. Appl. Environ. Microbiol. 2000, 66, 80-86. [CrossRef] [PubMed]

81. Martinkova, L.; Patakova-Juzlova, P.; Krent, V.; Kucerova, Z.; Havlicek, V.; Olsovsky, P.; Hovorka, O.; Rihova, B.; Vesely, D.; Vesela, D.; et al. Biological activities of oligoketide pigments of Monascus purpureus. Food Addit. Contam. 1999, 16, 15-24. [CrossRef] [PubMed]

82. Brown, R.S. Hepatitis C and liver transplantation. Nature 2005, 436, 973-978. [CrossRef] [PubMed]

83. Berenguer, M.; López-Labrador, F.X.; Wright, T.L. Hepatitis C and liver transplantation. J. Hepatol. 2001, 35, 666-678. [CrossRef]

84. Appel, N.; Schaller, T.; Penin, F.; Bartenschlager, R. From structure to function: New insights into hepatitis C virus RNA replication. J. Biol. Chem. 2005, 281, 9833-9836. [CrossRef] [PubMed]

85. Lloyd-Jones, D.; Adams, R.J.; Brown, T.M.; Carnethon, M.; Dai, S.; De Simone, G.; Ferguson, T.B.; Ford, E.; Furie, K.; Gillespie, C.; et al. Executive summary: Heart disease and stroke statistics-2010 update: A report from the american heart association. Circulation 2010, 121, 948-954. [PubMed]

86. Kiernan, T.J.; Yan, B.P.; Jaff, M.R. Antiplatelet therapy for the primary and secondary prevention of cerebrovascular events in patients with extracranial carotid artery disease. J. Vasc. Surg. 2009, 50, 431-439. [CrossRef] [PubMed]

87. Tabas, I.; García-Cardeña, G.; Owens, G.K. Recent insights into the cellular biology of atherosclerosis. J. Cell Biol. 2015, 209, 13-22. [CrossRef] [PubMed]

88. Lusis, A.J. Atherosclerosis. Nature 2000, 407, 233-241. [CrossRef] [PubMed]

89. Endo, A. Chemistry, biochemistry, and pharmacology of HMG-CoA reductase inhibitors. Klin. Wochenschr. 1988, 66, 421-427. [CrossRef] [PubMed]

90. Gordon, D.J.; Probstfield, J.L.; Garrison, R.J.; Neaton, J.D.; Castelli, W.P.; Knoke, J.D., Jr.; Bangdiwala, S.; Tyroler, H.A. High-Density Lipoprotein Cholesterol and Cardiovascular Disease Four Prospective American Studies. Circulation 1988, 79, 8-15. [CrossRef]

91. Boden, W.E. High-density lipoprotein cholesterol as an independent risk factor in cardiovascular disease: Assessing the data from framingham to the veterans affairs high-density lipoprotein intervention trial. Am. J. Cardiol. 2000, 86, 19-22. [CrossRef]

92. Barter, P.J.; Brewer, H.B.; Chapman, M.J.; Hennekens, C.H.; Rader, D.J.; Tall, A.R. Cholesteryl ester transfer protein: A novel target for raising HDL and inhibiting atherosclerosis. Arterioscler. Thromb. Vasc. Biol. 2003, 23, 160-167. [CrossRef] [PubMed]

93. Shah, P.K. Inhibition of CETP as a novel therapeutic strategy for reducing the risk of atherosclerotic disease. Eur. Heart J. 2007, 28, 5-12. [CrossRef] [PubMed]

94. Ranalletta, M.; Bierilo, K.K.; Chen, Y.; Milot, D.; Chen, Q.; Tung, E.; Houde, C.; Elowe, N.H.; Garcia-Calvo, M.; Porter, G.; et al. Biochemical characterization of cholesteryl ester transfer protein inhibitors. J. Lipid Res. 2010, 51, 2739-2752. [CrossRef] [PubMed]

95. Mohammadpour, A.H.; Akhlaghi, F. Future of cholesteryl ester transfer protein (CETP) inhibitors: A pharmacological perspective. Clin. Pharmacokinet. 2013, 52, 615-626. [CrossRef] [PubMed]

96. Rader, D.J.; Degoma, E.M. Future of cholesteryl ester transfer protein inhibitors. Annu. Rev. Med. 2014, 65, 385-403. [CrossRef] [PubMed]

97. Zern, T.L.; West, K.L.; Fernandez, M.L. Grape polyphenols decrease plasma triglycerides and cholesterol accumulation in the aorta of ovariectomized guinea pigs. J. Nutr. 2003, 133, 2268-2272. [PubMed]

98. Cheuk, K.L.; Zhang, Z.; Yu, H.; Tsang, S.Y.; Huang, Y.; Zhen, Y.C. Apple polyphenols inhibit plasma CETP activity and reduce the ratio of non-HDL to HDL cholesterol. Mol. Nutr. Food Res. 2008, 52, 950-958.

99. Hirata, H.; Takazumi, K.; Segawa, S.; Okada, Y.; Kobayashi, N.; Shigyo, T.; Chiba, H. Xanthohumol, a prenylated chalcone from Humulus lupulus L.; Inhibits cholesteryl ester transfer protein. Food Chem. 2012, 134, 1432-1437. [CrossRef] [PubMed]

100. Shinkai, H. Cholesteryl ester transfer-protein modulator and inhibitors and their potential for the treatment of cardiovascular diseases. Vasc. Health Risk Manag. 2012, 8, 323-331. [CrossRef] [PubMed]

101. Tint, G.S.; Irons, M.; Elias, E.R.; Batta, A.K.; Frieden, R.; Chen, T.S.; Salen, G. Defective cholesterol biosynthesis associated with the Smith-Lemli-Opitz syndrome. N. Engl. J. Med. 1994, 330, 107-113. [CrossRef] [PubMed] 
102. Cerqueira, N.M.F.S.A.; Oliveira, E.F.; Gesto, D.S.; Santos-Martins, D.; Moreira, C.; Moorthy, H.N.; Ramos, M.J.; Fernandes, P.A. Cholesterol Biosynthesis: A Mechanistic Overview. Biochemistry 2016, 55, 5483-5506. [CrossRef] [PubMed]

103. Goswami, S.; Vidyarthi, A.S.; Bhunia, B.; Mandal, T. A review on lovastatin and its production. J. Biochem. Technol. 2012, 4, 581-587.

104. Klimek, M.; Wang, S.; Ogunkanmi, A. Safety and efficacy of red yeast rice (Monascus purpureus) as an alternative therapy for hyperlipidemia. P T Peer Rev. J. Formul. Manag. 2009, 34, 313-327.

105. Tobert, J.A. Case history: Lovastatin and beyond: The history of the HMG-CoA reductase inhibitors. Nat. Rev. Drug Discov. 2003, 2, 517-526. [CrossRef] [PubMed]

106. Finkelstein, E.A.; Trogdon, J.G.; Cohen, J.W.; Dietz, W. Annual medical spending attributable to obesity: Payer-and service-specific estimates. Health Aff. 2009, 28, 822-831. [CrossRef] [PubMed]

107. Trogdon, J.G.; Finkelstein, E.A.; Hylands, T.; Dellea, P.S.; Kamal-Bahl, S.J. Indirect costs of obesity: A review of the current literature. Obes. Rev. 2008, 9, 489-500. [CrossRef] [PubMed]

108. Harmon, A.W.; Harp, J.B. Differential effects of flavonoids on 3T3-L1 adipogenesis and lipolysis. Am. J. Physiol. Cell Physiol. 2001, 280, C807-C813. [CrossRef] [PubMed]

109. Choi, I.; Park, Y.; Choi, H.; Lee, E.H. Anti-adipogenic activity of rutin in 3T3-L1 cells and mice fed with high-fat diet. Biofactors 2006, 26, 273-281. [CrossRef] [PubMed]

110. Lee, M.-S.; Kim, C.-T.; Kim, Y. Green tea (-)-epigallocatechin-3-gallate reduces body weight with regulation of multiple genes expression in adipose tissue of diet-induced obese mice. Ann. Nutr. Metab. 2009, 54, 151-157. [CrossRef] [PubMed]

111. Ejaz, A.; Wu, D.; Kwan, P.; Meydani, M. Curcumin inhibits adipogenesis in 3T3-L1 adipocytes and angiogenesis and obesity in C57/BL mice. J. Nutr. 2009, 139, 919-925. [CrossRef] [PubMed]

112. Hussein, H.; Brasel, J. Toxicity, metabolism and impact of mycotoxins on human and animals. Toxicology 2001, 167, 101-134. [CrossRef]

113. Comerio, R.; Fernandez Pinto, V.E.; Vaamonde, G. Influence of water activity on Penicillium citrinum growth and kinetics of citrinin accumulation in wheat. Int. J. Food Microbiol. 1998, 42, 219-223. [CrossRef]

114. Lin, Y.C.; Yres, J.C.; Koehler, P.E. Effect of temperature cycling on the production of patulin and citrinin. J. Food Sci. 1981, 46, 974-975. [CrossRef]

115. Chen, F.; Hu, X. Study on red fermented rice with high concentration of monacolin $\mathrm{K}$ and low concentration of citrinin. Int. J. Food Microbiol. 2005, 103, 331-337. [CrossRef] [PubMed]

116. European Food Safety Authority (EFSA). Scientific Opinion on the risks for public and animal health related to the presence of citrinin in food and feed. EFSA J. 2012, 10, 1-82.

117. Lee, C.L.; Wang, J.J.; Pan, T.M. Red mold rice extract represses amyloid beta peptide-induced neurotoxicity via potent synergism of anti-inflammatory and antioxidative effect. Appl. Microbiol. Biotechnol. 2008, 79, 829-841. [CrossRef] [PubMed]

118. Akihisa, T.; Tokuda, H.; Ukiya, M.; Kiyota, A.; Yasukawa, K.; Sakamoto, N.; Kimura, Y.; Suzuki, T.; Takayasu, J.; Nishino, H. Anti-tumor-initiating effects of monascin, an azaphilonoid pigment from the extract of Monascus pilosus fermented rice (red-mold rice). Chem. Biodivers. 2005, 2, 1305-1309. [CrossRef] [PubMed]

119. Su, N.W.; Lin, Y.L.; Lee, M.H.; Ho, C.Y. Ankaflavin from Monascus-fermented red rice exhibits selective cytotoxic effect and induces cell death on Hep G2 cells. J. Agric. Food Chem. 2005, 53, 1949-1954. [CrossRef] [PubMed]

120. Hong, M.Y.; Seeram, N.P.; Zhang, Y.; Heber, D. Anticancer effects of Chinese red yeast rice versus monacolin K alone on colon cancer cells. J. Nutr. Biochem. 2008, 19, 448-458. [CrossRef] [PubMed]

121. Lin, W.-Y.; Hsu, W.-Y.; Hish, C.-H.; Pan, T.-M. Proteome changes in Caco-2 cells treated with Monascus_Fermented red mold rice extract. J. Agric. Food Chem. 2007, 55, 8987-8994. [CrossRef] [PubMed]

122. Ho, B.-Y.; Pan, T.-M. The Monascus metabolite monacolin K reduces tumor progression and metastasis of Lewis lung carcinoma cells. J. Agric. Food Chem. 2009, 57, 8258-8265. [CrossRef] [PubMed]

123. Cheng, M.-J.; Chen, J.-J.; Wu, M.-D.; Yang, P.-S.; Yuan, G.-F. Isolation and structure determination of one new metabolite isolated from the red fermented rice of Monascus purpureus. Nat. Prod. Res. 2010, 24, 979-988. [CrossRef] [PubMed] 
124. Pan, T.M.; Tsai, R.L.; Ho, B.Y. Red mold rice mitigates oral carcinogenesis in 7,12-dimethyl-1,2-benz[a] anthracene-induced oral carcinogenesis in hamster. Evid. Based Complement. Altern. Med. 2011, 2011. [CrossRef]

125. Hsu, W.H.; Lee, B.H.; Pan, T.M. Protection of Monascus-fermented dioscorea against DMBA-induced oral injury in hamster by anti-inflammatory and antioxidative potentials. J. Agric. Food Chem. 2010, 58, 6715-6720. [CrossRef] [PubMed]

126. Hsu, W.H.; Lee, B.H.; Pan, T.M. Effects of red mold dioscorea on oral carcinogenesis in DMBA-induced hamster animal model. Food Chem. Toxicol. 2011, 49, 1292-1297. [CrossRef] [PubMed]

127. Lakrod, K.; Chaisrisook, C.; Yongsmith, B.; Skinner, D.Z. RAPD analysis of genetic variation within a collection of Monascus spp. isolated from red rice (ang-kak) and sofu. Mycol. Res. 2000, 104, 403-408. [CrossRef]

128. Kim, J.G.; Choi, Y.D.; Chang, Y.J.; Kim, S.U. Genetic transformation of Monascus purpureus DSM1379. Biotechnol. Lett. 2003, 25, 1509-1514. [CrossRef] [PubMed]

129. Campoy, S.; Pérez, F.; Martín, J.F.; Gutiérrez, S.; Liras, P. Stable transformants of the azaphilone pigment-producing Monascus purpureus obtained by protoplast transformation and Agrobacterium-mediated DNA transfer. Curr. Genet. 2003, 43, 447-452. [CrossRef] [PubMed]

130. Wang, L.; Wang, W.; Xu, G. Promotion of Monacolin K production by Agrobacterium tumefaciens-mediated transformation in Monascus albidus 9901. Curr. Microbiol. 2011, 62, 501-507. [CrossRef] [PubMed]

131. Shimizu, T.; Kinoshita, H.; Ishihara, S.; Sakai, K.; Nagai, S. Polyketide synthase gene responsible for citrinin biosynthesis in Monascus purpureus. Appl. Environ. Microbiol. 2005, 71, 1-6. [CrossRef] [PubMed]

132. Shimizu, T.; Kinoshita, H.; Nihira, T. Identification and in vivo functional analysis by gene disruption of ctnA, an activator gene involved in citrinin biosynthesis in Monascus purpureus. Appl. Environ. Microbiol. 2007, 73, 5097-5103. [CrossRef] [PubMed]

133. Chen, Y.; Tseng, C.; Liaw, L.; Wang, C.; Chen, I.; Wu, W.; Wu, M.; Yuan, G. Cloning and characterization of monacolin K biosynthetic gene cluster from Monascus pilosus. J. Agric. Food Chem. 2008, 56, 5639-5646. [CrossRef] [PubMed]

134. Chen, Y.I.P.; Yuan, G.F.; Hsieh, S.Y.; Lin, Y.U.S.; Wang, W.Y.I.; Liaw, L.I.L.; Tseng, C.P. Identification of the mokh gene encoding transcription factor for the upregulation of monacolin $\mathrm{k}$ biosynthesis in Monascus pilosus. J. Agric. Food Chem. 2010, 58, 287-293. [CrossRef] [PubMed]

135. Yang, Y.; Li, L.; Li, X.; Shao, Y.; Chen, F. MrflbA, encoding a putative FlbA, is involved in aerial hyphal development and secondary metabolite production in Monascus ruber M-7. Fungal Biol. 2012, 116, 225-233. [CrossRef] [PubMed]

136. Balakrishnan, B.; Karki, S.; Chiu, S.H.; Kim, H.J.; Suh, J.W.; Nam, B.; Yoon, Y.M.; Chen, C.C.; Kwon, H.J. Genetic localization and in vivo characterization of a Monascus azaphilone pigment biosynthetic gene cluster. Appl. Microbiol. Biotechnol. 2013, 97, 6337-6345. [CrossRef] [PubMed] 